\title{
Survei Keterampilan Gerak Dasar Lokomotor, Nonlokomotor, dan Manipulatif Siswa Putri Kelas VII
}

\author{
Muhammad Anwar Firdaus*, Siti Nurrochmah \\ Universitas Negeri Malang, Jl. Semarang No. 5 Malang, Jawa Timur, Indonesia \\ *Penulis korespondensi, Surel: muhammadanwarfirdaus408@gmail.com
}

Paper received: 3-5-2021; revised: 24-5-2021; accepted: 28-5-2021

\begin{abstract}
Abstrak
Penelitian ini bertujuan mengetahui kondisi keterampilan gerak dasar lokomotor, nonlokomotor, dan manipulatif siswa MTs Negeri 1 Kota Malang. Menggunakan rancangan deskriptif kuantitatif dengan metode survei. Sampel penelitian 88 siswa putri. Hasil: (1) kondisi keterampilan gerak lokomotor unsur lari dominan (baik 35 persen), loncat (kurang baik 35 persen), lompat (kurang baik 36 persen). (2) Nonlokomotor back up punggung(cukup 40 persen), back up kaki (kurang baik 36 persen). (3) Manipulatif lempar tangkap (cukup 33 persen) chest pass (kurang baik 44 persen). simpulan hasil analisis data keterampilan gerak lokomotor, nonlokomotor dan manipulatif pada siswa putri kelas VII MTs Negeri Malang tergolong belum baik.
\end{abstract}

Kata kunci: gerak dasar; lokomotor; nonlokomotor; manipulatif

\section{Pendahuluan}

Gerak dasar merupakan hal penting dalam pendidikan jasmani, karena pada pembelajaran dasar awal awalnya Pendidikan jasmani sudah diajarkan di SD dengan aspek gerak yang lebi dominan. Mu'arifin (2009) berpendapat bahwa dalam bidang olahraga, asas atau dasar merupakan suatu prinsip dasar atau pandangan dasar (basic principle) serta konsep seorang yang akan melakukan suatu hal seperti olahraga maupun dalam beberapa cabang olahraga yang lain, dengan mencapai gerak yang maksimal serta kekuatan energi yang dikeluarkan secara minimal. Seorang individu harus menguasai dasar dalam semua bidang khususnya olahraga yang diminatinya, umumnya yang merupakan titik tolak mengapa seseorang mempelajari olahraga yang diminati atau ditekuni tersebut. Berarti keterampilan atau kemampuan dasar sangat berperan penting untuk menarik minat seorang individu.

Sugito dan Hanif (2015) berpendapat bahwa keterampilan gerak dasar dibagi menjadi tiga macam keterampilan gerak, yaitu (1) keterampilan gerak lokomotor (2) keterampilan gerak nonlokomotor, dan (3) keterampilan gerak manipulatif. Dengan arti bahwa ketiga keterampilan ini mempunyai pengertian sendiri. Gallahue \& Donelly (2003) berpendapat mengenai gerak dasar lokomotor, nonlokomotor, manipulatif sebagai berikut.

Total body movements in wich the body is propelled in an upright posture from one point to another in a roughly horizontal or vertical direction are called lokomotor skill. movements such as walking, running leaping, hopping, jumping, skipping galloping, and sledding are generally considered to be fundamental locomotor skills. Nonlocomotor skills include banding, streaching, twisting, and curling action. These action do not travel trought space but are performed with in one's personal space at a hight, medium or low level. Both locomotor and nonlocomotor skills are necessary for purposeful and controlled movements trought or anvironment and are basic to the numerous skills necessary for games, dance and gymnastic activities. Manipulative skills, as referred to here, are gross body movements in which force is imparted to or received from objects. 
Manipulative movements such as throwing, catching, kicking, trapping, striking, volleying,bouncing and ball rolling are generally considered to be fundamental manipulative skills. Simpulan dari pendapat tersebut gerak lokomotor merupakan gerak yang menyebabkan perpindahan titik tumpu meskipun hanya meninggalkan tumpuan dari tempat $\mathrm{A}$ ke $\mathrm{B}$, meskipun beberapa detik seperti meloncat dan melompat di tempat dikatakan gerak lokomotor, sedangkan gerak non lokomotor merupakan gerak yang tidak akan meninggalkan titik tumpunya seperti gerakan berdiri di tempat, sit up, back up pada umumnya, dan untuk gerak manipulatif merupakan gerakan yang menggunakan objek control dalam pelaksanaanya seperti menendang, melempar dan lainya.

Berdasarkan hasil observasi dan wawancara dengan musyawarah guru mata pelajaran pendidikan jasmani olahraga dan kesehatan serta penanggung jawab dalam pelajaran pendidikan jasmani dan olahraga khususnya untuk siswa putri, kami menemukan permasalahan yaitu, dalam setiap tahun dan setiap kelas ada beberapa siswa putri pada saat proses kegiatan pembelajaran pendidikan jasmani berlangsung yang melibatkan keterampilan gerak lokomotor, nonlokomotor serta manipulatif, dalam pembelajarannya banyak mengalami kesulitan. Sebelumnya memang dalam proses pembelajaran pendidikan jasmani dan kesehatan khususnya untuk siswa putri kelas VII di MTs Negeri 1 Kota Malang belum pernah dilakukan tes mengenai keterampilan gerak dasar, yang meliputi gerak lokomotor, nonlokomotor serta manipulatif.

Seharusnya siswa yang telah mengikuti proses pembelajaran pendidikan jasmani mengenai gerak dasar yang sudah dilakukan ketika SD, mampu melakukan kemampuan gerak dasar tersebut dengan benar, namun kenyataannya terdapat beberapa gerakan yang dilakukan oleh siswa mengalami kesulitan, serta dapat mempraktikan ke dalam berbagai permainan yang dikuasai dengan optimal dalam pembelajaran PENJAS pada jenjang SMP atau MTS yang akan diajarkan, Lantai (2014) menyatakan bahwa pembelajaran juga berarti meningkatkan kemampuan kognitif, afektif, maupun keterampilan siswa. Artinya bahwa dalam pembelajaran yang sudah diajarkan dan dipelajari dalam proses pembelajaran sebelumnya, seharusnya sudah dapat meningkatkan kemampuan kognitif, afektif maupun berupa keterampilan atau dalam kemampuan gerak dasar siswa. sehubungan dengan pendapat tersebut gerak dasar di sekolah dasar yang sudah diajarkan seharusnya dapat meningkatkan gerak dasar lokomotor, nonlokomotor, dan manipulatif di MTs Negeri 1 Kota Malang.

Rahyubi (2012) menyatakan bahwa hakikat dari belajar sendiri memiliki arti proses berlangsungnya hidup yang secara sadar atau tidak harus dijalani semua manusia untuk mencapai berbagai macam kompetensi, pengetahuan, keterampilan, dan sikap yang telah dilakukan. Rusman (2017) berpendapat bahwa belajar merupakan proses interaksi terhadap semua situasi yang terdapat dalam lingkungan.

Dalam interaksi dengan lingkungan seorang akan melihat dan akan berpikir mengenai suatu hal yang menyebabkan seorang individu belajar mengenai lingkungan sekitarnya atau menyesuaikan. Gasong (2018) mengungkapkan bahwa belajar mempunyai ciri-ciri tersendiri yaitu belajar adalah proses yang dapat dilakukan oleh manusia, maupun sedikit dengan beberapa hewan. Namun kemampuan manusia untuk belajar merupakan karakteristik penting yang dapat membedakan manusia satu dengan manusia yang lain. Secara formal belajar bisa dilakukan dalam berbagai lembaga yaitu sekolah, dan pendidikan nonformal berupa tempat 
kursus dan pelatihan, serta lembaga informal yang diawali dari keluarga yang tidak terbatas waktu.

Dapat disimpulkan bahwa belajar sendiri merupakan aktivitas dan usaha sadar yang telah dilakukan dan mempunyai hasil berupa penambahan ilmu pengetahuan atau kemahiran berdasar apa yang orang lihat dan dilakukan berupa pengalaman berpikir yang didapat dalam lingkungan hidup dengan waktu yang tidak berbatas. Oleh karena itu, apabila ada seorang peserta didik tidak ada perubahan tingkah laku, wawasan, kecakapan pengetahuan yang positif atau baik dalam perkembanganya, maka dapat dikatakan belajar yang dilakukan belum benar atau belum sempurna.

Pembelajaran merupakan usaha yang dilakukan oleh pendidik kepada peserta didik agar seorang peserta didik mampu belajar dengan baik. Proses belajar akan terjadi sepanjang hayat seorang individu serta dapat berlaku di manapun dan kapanpun (Suardi, 2018). Dari pendapat yang telah dikemukakan dapat disimpulkan bahwa pembelajaran merupakan proses interaksi yang dilakukan peserta didik dengan pendidik dan sumber belajar yang lain seperti buku maupun media yang lain sebagai bahan ajar dan rujukan, yang sudah dirancang serta terencana secara matang dan sistematis.

Terdapat tujuan dan fungsi dalam pendidikan jasmani. Wiarto (2015) berpendapat bahwa ada beberapa tujuan dari Pendidikan jasmani. 1) Mengembangkan sikap sportif, jujur, disiplin, serta tanggung jawab memiliki rasa kerjasama, memiliki kepercayaan diri dan demokratis. 2)Mengembanagkan ketrampilan gerak dan ketrampilan Teknik serta strategi berbagai permainan dalam olahraga, aktivitas pengembangan, senam, aktivitas aquatic, ritmik, dan Pendidikan luar kelas. 3) Mengembangkan mengelola keterampilan diri sendiri dalam upaya mengembangkan dan pemeliharaan kebugaran jasmani serta pola hidup sehat melalui aktivitas jasmani. 4) Menumbuhkan karakter yang kuat melalui internalisasi nilai-nilai dalam Pendidikan jasmani. 5) Membangun kepribadian yang kuat, memiliki rasa cintai damai, memiliki jiwa sosial yang tinggi, dan memiliki rasa toleransi yang tinggi terhadap etnis, agama dan budaya. 6) Mengetahui konsep Pendidikan jasmani sebagai informasi untuk mengisi waktu luang, mencapai kebugaran dan kesehatan dan pola hidup sehat.

Tujuan dan fungsi dalam pendidikan jasmani selain untuk meningkatkan keterampilan untuk bergerak dan meningkatkan kebugaran jasmani namun juga untuk mengembangkan karakter yang kuat yang baik serta sikap sportif antar individu maupun kelompok, serta memiliki jiwa sosial yang tinggi dengan rasa toleransi terhadap etnis, budaya, maupun dalam kehidupan masyarakat dalam beragama.

Kemampuan bergerak merupakan hal yang penting dalam kehidupan sehari-hari, dalam pembelajaran pendidikan jasmani kemampuan untuk bergerak sangat penting dan fundamental yang harus diajarkan karena merupakan aspek yang dominan dalam pelaksanaan pembelajaran yang akan dilakukan oleh siswa. Sehubungan dengan hal tersebut. menurut Nurhasan (2003) menyatakan bahwa motor ability (kemampuan gerak) adalah kemampuan yang umum seseorang untuk bergerak. Berarti kemampuan gerak merupakan hal yang fundamental yang umum yang dilakukan manusia dalam kehidupan sehari-hari seperti berjalan berlari,meloncat,melompat, melempar, menangkap merupakan kemampuan untuk bergerak. 
Sedangkan untuk keterampilan dapat disamakan dengan kata kecekatan, seseorang bisa dikatakan sebagai orang terampil apabila orang tersebut mampu mengerjakan sesuatu dan menyelesaikan pekerjaanya dengan cepat dan benar (Soemarjadi, 1991). Berarti untuk mencapai keterampilan seharusnya seseorang harus menguasai yang namanya kemampuan gerak dasar (motor ability) karena kemampuan ini masih bersifat umum, sehingga orang dikatakan terampil apabila dapat mengerjakan sesuatu dengan cepat, cekatan dan benar. Frits (2013: 87) menyatakan bahwa.

Fundamental movement stills are divided into three categories: 1) Locomotor/Moving: involves the body moving in any way. Skills in this category include walking,running, cutting, pivoting, jumping, sliding, and skipping. 2) Non-locomotor/Stability Skills: involve maintaining static balance in one place or dynamic balance while in motion. Skills in this category include bending,stretching, twisting, turning, lifting, landing after jump, standing on one foot, and controlled falling. 3) Manipulative Skills : involve handling and control-Ting objects with the hand, the foot, or an implement.

Pendapat tersebut membagi gerak dasar menjadi tiga jenis yaitu gerak lokomotor, nonlokomotor dan manipulatif. Gerak lokomotor merupakan gerak yang dapat memindahkan tempat seperti berjalan, berlari, berputar, melompat. Gerak non lokomotor merupakan gerak yang lebih statis atau tetap di tempat seperti membungkuk, berdiri satu kaki dan yang lain. Sedangkan untuk gerak manipulatif gerakan yang melibatkan atau mengontrol suatu objek dengan tangan kaki atau alat yang akan dikendalikan.

Dalam kehidupan sehari- hari maupun dalam proses belajar seorang siswa maupun seorang individu pasti mempunyai karakter tersendiri. Karakter merupakan aspek seseorang untuk berperilaku, mempercayai, berperasaan, dan tindakan yang saling terkait satu sama lain sehingga jika seseorang menginginkannya untuk mengubah karakter tertentu, mereka perlu mengatur ulang elemen karakter dasar mereka (Wijaya \& Helaluddin, 2018). Menjadi penting karena karakter akan mempengaruhi seseorang untuk hidup dalam bermasyarakat dan menentukan tindakan maupun perilaku yang akan dilakukan. Siswa dalam proses pembelajaran, khususnya di jenjang SMP atau MTs seorang siswa mempunyai karakter yang tidak sama dengan seorang yang sudah usia dewasa.

Siswa SMP atau MTs merupakan siswa yang pada masa pertumbuhan remaja awal, yang berlangsung kira-kira dari usia 13-16 tahun, awal masa remaja biasanya disebut dalam masa usia belasan dan mempunyai ciri- ciri tersendiri.

Hurlock (2010) masa remaja mempunyai ciri- ciri tertentu yang membedakannya dari periode sebelum dan sesudahnya. 1) Merupakan periode yang penting karena adanya transisi. 2)Merupakan masa periode peralihan dari masa anak-anak menuju masa remaja awal. 3) Masa remaja sebagai periode perubahan meningginya emosi. 4) Masa remaja merupakan masa mencari identitas. 5) Masa remaja menjadi ambang dari kedewasaan. 6) Masa remaja merupakan masa yang bermasalah karena sebelumnya setiapa ada permasalahan yang menyeleseikan guru maupun orang tua. 7) Masa yang menimbulkan ketakutan. 8) Masa yang tidak realistik

Karakter atau ciri- ciri yang dimiliki seorang siswa SMP cenderung dikatan pada masa transisi dari anak-anak ke masa remaja awal yang akan banyak mempengaruhi pskikologi anak dan belum dapat mengendalikan emosi yang dimiliki/ cepat marah dan susah di atur, karena 
sebagai periode awal masa remaja yang sebelumnya terdapat masalah lebih kepada orang tua atau guru sebagai penyelesaiannya, sedangkan pada tahap remaja awal seorang anak akan mencari jati diri atau identitas dirinya sehingga anak tersebut susah di atur dan cepat marah/emosi.

Sedangkan dalam bidang pendidikan jasmani seorang siswa, khususnya untuk siswa putri mempunyai perbedaan dengan seorang siswa putra yang memengaruhi hasil gerak dalam pelaksanaan pembelajarannya. Amien (1996) ada perbedaan yang meliputi jenis kelamin serta kultur atau budaya yang dapat mempengaruhi skor dan nilai yang lebih rendah yang diperoleh seorang siswa perempuan dibandingkan dengan siswa putra. Berarti faktor genetik merupakan faktor yang lebih dominan dan bawaan seorang perempuan berpengaruh, serta budaya dalam masayarakat tersebut yang akan menjadikan seorang perempuan menjadi berbeda atau sama dalam melakukan suatu hal atau kegiatan yang lain.

Kemampuan motorik seorang perempuan mempunyai perbedaan dari seorang laki-laki, siswa putri cenderung mempunyai kemampuan motorik yang lebih lemah karena kurangnya kesempatan dan latihan serta gen atau keturunan kodrat dari lahir yang mempengaruhi kemampuan bergerak seorang siswa perempuan. Selain dari faktor jenis kelamin ada beberapa faktor yang mempengaruhi gerak pada anak atau siswa perempuan.

Menurut Yudrik dan Jahja (2011) menyimpulkan ada 6 perbedaan pokok, yaitu: 1) Anak laki-laki lebih banyak bermain di luar daripada anak perempuan. 2) Anak laki-laki bermain dalam kelompok yang lebih besar daripada anak perempuan. 3) Permainan anak laki-laki terjadi dalam kelompok yang terdiri dari berbagai usia. Adapun anak perempuan bermain dengan anak seusianya. 4) Anak perempuan sering memainkan permainan anak laki laki daripada anak laki-laki memainkan permainan anak perempuan. 5) Anak laki-laki lebih banyak memainkan permainan yang bersifat pertandingan daripada anak perempuan. 6) Permainan anak laki-laki berlangsung lebih lama daripada permainan anak perempuan.

Perbedaan kemampuan gerak dari anak laki-laki dibandingkan seorang perempuan menurut penjelasan tersebut karena kesempatan untuk bergerak sangat terbatas menjadikan seorang anak perempuan mempunyai kemampuan gerak atau motorik lebih rendah dibandingkan seorang anak laki-laki dari segi kelompok gerak dalam bermain lebih besar menjadikan seorang laki-laki lebih aktif bergerak dalam kelompok besar dibanding kelompok yang lebih kecil anak perempuan. Kesempatan anak laki-laki yang lebih besar, selain faktor jenis kelamin kebiasaan dan kesempatan untuk melakukan gerak mempengaruhi seseorang untuk lebih menguasai kemampuan gerak yang lebih kompleks.

Kemampuan dan keterampilan motorik berkembang dalam urutan yang pasti, dan norma-norma umur kerap digunakan untuk mengukur kemajuan perkembangan (Upton, 2012). Dengan pendapat tersebut bahwa siswa putri di jenjang SMP atau pada masa sekolah menengah pertama merupakan anak yang \pm usia 12,13 dan merupakan masa remaja awal pada masa transisi, dari anak SD umumnya yang masih menguasai keterampilan atau kemampuan gerak dasar yang akan dikembangkan pada pembelajaran pertumbuhan gerak di jenjang sekolah menengah pertama. Terlebih siswa putri perkembangan geraknya umumnya lebih lambat dibanding anak laki-laki. 


\section{Metode}

Populasi penelitian ini melibatkan siswa putri kelas VII MTs Negeri 1 Kota Malang, yang terdiri dari lima kelas homogen siswa putri dan rata- rata per-kelas berjumlah 17 - 18 siswa putri, dengan populasi berjumlah 146 orang siswa putri, pengambilan sampel menggunakan teknik purposive sampling yaitu pengambilan sampel menggunakan pertimbangan atau tujuan tertentu berdasar pada ciri-ciri atau karakteristik siswa (Sugiyono, 2009). Dalam penelitian ini teknik pengambilan sampel tersebut berdasar pada karakteristik siswa putri yaitu siswa baru kelas VII tahun akademik atau tahun pelajaran 2019/2020. Mengingat jumlah kelas terdapat 5 kelas, maka pengambilan sampel menggunakan teknik purposive sampling (Sugiyono, 2009), dengan porsi sebesar 60\% pengambilan sampel dari keseluruhan populasi. Populasi berjumlah 146 siswa putri kelas VII MTs Negeri 1 Kota Malang, dengan sampel berjumlah 88 orang siswa putri.

\section{Hasil dan Pembahasan}

\subsection{Hasil}

Hasil Deskripsi Data Tes Keterampilan Gerak Lokomotor

Tabel 1. Deskripsi Data Hasil Tes Keterampilan Gerak Lokomotor

\begin{tabular}{|c|c|c|c|c|c|c|c|}
\hline \multirow[b]{2}{*}{ No } & \multirow{2}{*}{$\begin{array}{c}\text { Aspek } \\
\text { gerak } \\
\text { lokomotor }\end{array}$} & \multirow[b]{2}{*}{ Jenis tes } & \multicolumn{5}{|c|}{ Ukuran statistik } \\
\hline & & & Min & Maks & Mean & Modus & Median \\
\hline 1. & Lari & Lari zig-zag & $\begin{array}{l}10,96 \\
\text { detik }\end{array}$ & $\begin{array}{l}6,90 \\
\text { detik }\end{array}$ & $\begin{array}{l}8,75 \\
\text { detik }\end{array}$ & $\begin{array}{c}8,5 \\
\text { detik }\end{array}$ & $\begin{array}{c}8,72 \text { dan } \\
8,75 \\
\text { detik }\end{array}$ \\
\hline 2. & Loncat & $\begin{array}{l}\text { Loncat jauh } \\
\text { tanpa awalan }\end{array}$ & $93 \mathrm{~cm}$ & $\begin{array}{l}173 \\
\mathrm{~cm}\end{array}$ & $\begin{array}{c}125,23 \\
\mathrm{~cm}\end{array}$ & $\begin{array}{l}120 \\
\mathrm{~cm}\end{array}$ & $\begin{array}{l}123 \text { dan } \\
125 \mathrm{~cm}\end{array}$ \\
\hline 3. & Lompat & $\begin{array}{l}\text { Lompat jauh } \\
\text { menggunakan } \\
\text { awalan }\end{array}$ & $\begin{array}{c}205 \\
\mathrm{~cm}\end{array}$ & $\begin{array}{l}267 \\
\mathrm{~cm}\end{array}$ & $\begin{array}{c}231,82 \\
\mathrm{~cm}\end{array}$ & $\begin{array}{c}221 \\
\mathrm{~cm}\end{array}$ & $\begin{array}{l}231 \mathrm{dan} \\
231 \mathrm{~cm}\end{array}$ \\
\hline
\end{tabular}

Hasil Deskripsi Data Tes Keterampilan Gerak Nonlokomotor

Tabel 2. Deskripsi Data Hasil Tes Keterampilan Gerak Nonlokomotor

\begin{tabular}{ccccccc}
\hline \multirow{2}{*}{ No } & \multirow{2}{*}{ Jenis tes } & Min & Maks & Mean & Modus & Median \\
\hline 1. & Back Up punggung & $18 \mathrm{~cm}$ & $46 \mathrm{~cm}$ & $30,35 \mathrm{~cm}$ & $32 \mathrm{~cm}$ & 30 dan $30 \mathrm{~cm}$ \\
2. & Back Up Kaki & $13 \mathrm{~cm}$ & $50 \mathrm{~cm}$ & $28,01 \mathrm{~cm}$ & $25 \mathrm{~cm}$ & 28 dan $28 \mathrm{~cm}$ \\
\hline
\end{tabular}

Hasil Deskripsi Data Tes Keterampilan Gerak Manipulatif

Tabel 3. Deskripsi Data Hasil Tes Keterampilan Gerak Manipulatif

\begin{tabular}{|c|c|c|c|c|c|c|}
\hline \multirow{2}{*}{ No } & \multirow{2}{*}{ Jenis tes } & \multicolumn{5}{|c|}{ Ukuran statistik } \\
\hline & & Min & Maks & Mean & Modus & Median \\
\hline 1. & Lempar tangkap bola tenis & 4 kali & 15 kali & 8,57 kali & 10 kali & 9 dan 9 kali \\
\hline 2. & Chest pass & 4 kali & 12 kali & 7,86 kali & 7 kali & 8 dan 8 kali \\
\hline
\end{tabular}


Hasil Analisis Data Tes Keterampilan Gerak Lokomotor

Tabel 4. Analisis Data Hasil Tes Keterampilan Gerak Lokomotor

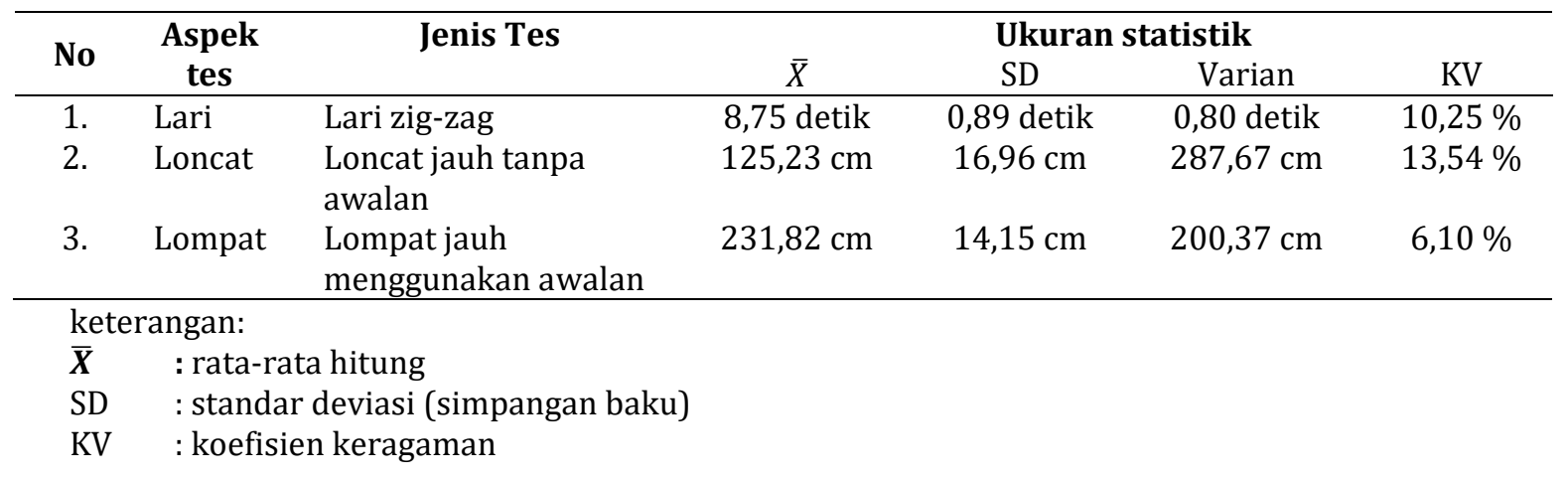

Hasil Distribusi Frekuensi Relatif dan Kriteria Tes Lari Zig-Zag 10,5 Meter Siswa Putri Kelas VII MTs Negeri I Kota Malang

Tabel 5. Distribusi Frekuensi Relatif dan Kriteria Tes Lari Zig-Zag 10,5 Meter Siswa Putri Kelas VII MTs Negeri I Kota Malang

\begin{tabular}{cccc}
\hline Interval & Fo & FR & Keterangan \\
\hline $7,84-6,95$ & 13 & $15 \%$ & Baik Sekali \\
$8,74-7,85$ & 31 & $35 \%$ & Baik \\
$9,64-8,75$ & 27 & $31 \%$ & Cukup \\
$10,54-9,65$ & 15 & $17 \%$ & Kurang Baik \\
$11,44-10,55$ & 2 & $2 \%$ & Tidak Baik \\
\hline
\end{tabular}

Hasil Sajian Analisis Data Bentuk Frekuensi Relatif Hasil Tes Lari Zig-Zag 10,5 Meter Data

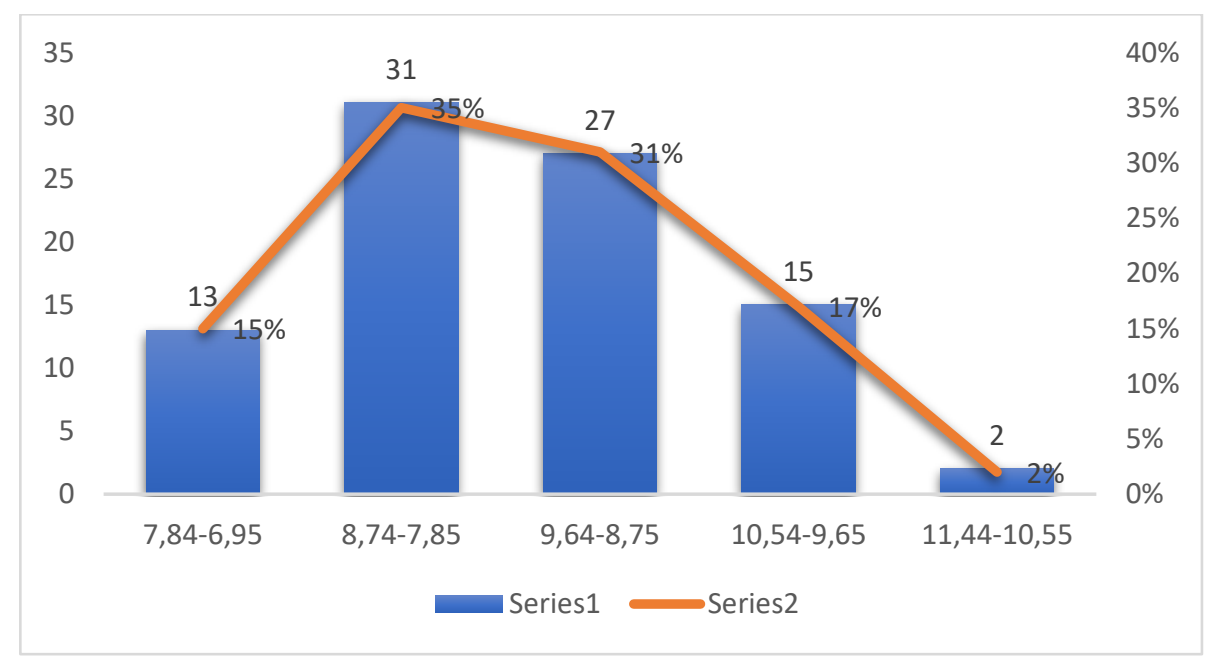

Gambar 1. Sajian Hasil Analisis Data Bentuk Frekuensi Relatif Hasil Tes Lari Zig-Zag 10,5 Meter Data 
Hasil Distribusi Frekuensi Relatif dan Kriteria Loncat Jauh Tanpa Awalan Siswa Putri Kelas VII MTs Negeri Kota Malang

Tabel 6. Distribusi Frekuensi Relatif dan Kriteria Loncat Jauh Tanpa Awalan Siswa Putri Kelas VII MTs Negeri I Kota Malang

\begin{tabular}{cccc}
\hline Interval & Fo & FR & Keterangan \\
\hline $159-176$ & 2 & $2 \%$ & Baik Sekali \\
$142-158$ & 13 & $15 \%$ & Baik \\
$125-141$ & 29 & $33 \%$ & Cukup \\
$108-124$ & 31 & $35 \%$ & Kurang Baik \\
$91-107$ & 13 & $15 \%$ & Tidak Baik \\
\hline
\end{tabular}

Hasil Sajian Analisis Data Bentuk Frekuensi Relatif Hasil Tes Loncat Jauh Tanpa Awalan Data

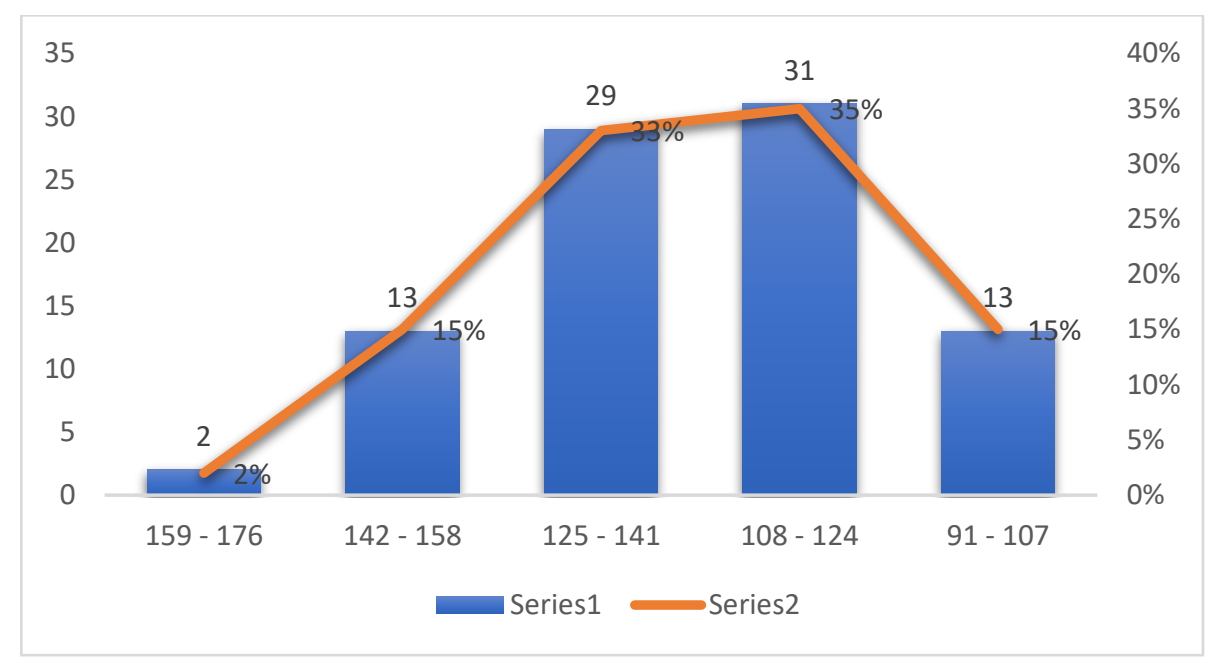

Gambar 2. Sajian Hasil Analisis Data Bentuk Frekuensi Relatif Hasil Tes Loncat Jauh Tanpa Awalan Data

Hasil Distribusi Frekuensi Relatif dan Kriteria Lompat Jauh Menggunakan Awalan Siswa Putri Kelas VII MTs Negeri I Kota Malang.

Tabel 7. Distribusi Frekuensi Relatif dan Kriteria Lompat Jauh Menggunakan Awalan Siswa Putri Kelas VII MTs Negeri I Kota Malang

\begin{tabular}{cccc}
\hline Interval & Fo & FR & Keterangan \\
\hline $260-273$ & 5 & $6 \%$ & Baik Sekali \\
$246-259$ & 9 & $10 \%$ & Baik \\
$232-245$ & 28 & $32 \%$ & Cukup \\
$218-231$ & 32 & $36 \%$ & Kurang Baik \\
$204-217$ & 14 & $16 \%$ & Tidak Baik \\
\hline
\end{tabular}

Hasil Sajian Analisis Data Bentuk Frekuensi Relatif Hasil Tes Lompat Jauh Menggunakan Awalan Data. 


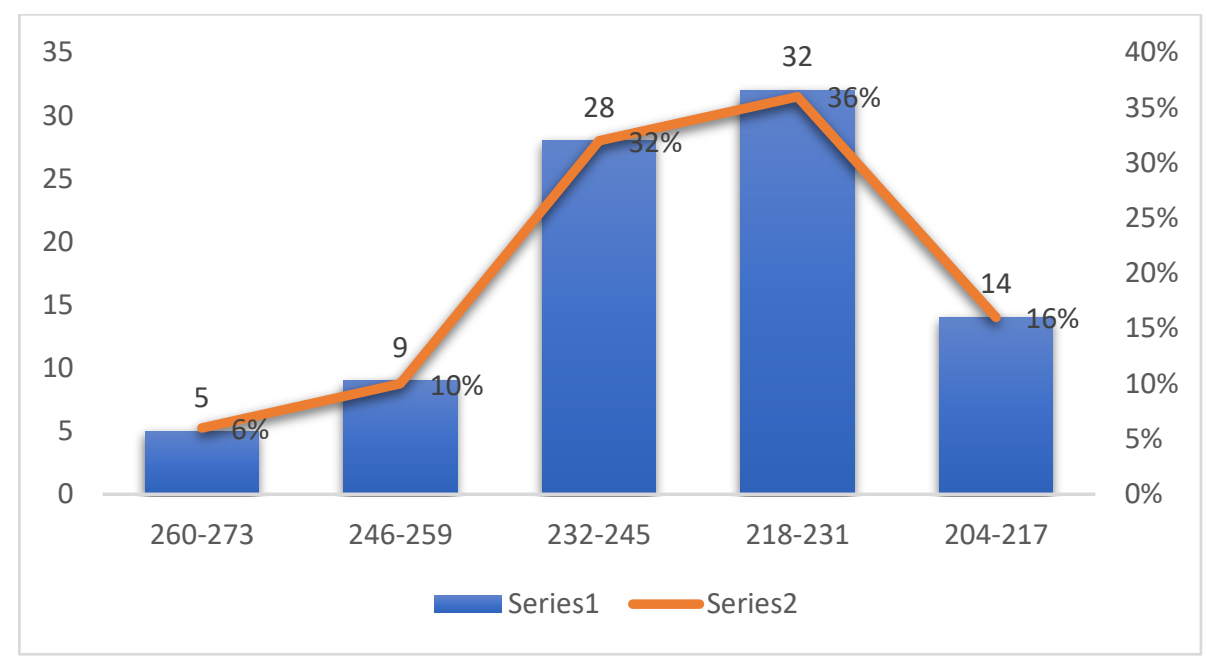

Gambar 3. Sajian Hasil Analisis Data Bentuk Frekuensi Relatif Hasil Tes Lompat Jauh Menggunakan Awalan Data

Hasil Analisis Data Tes Keterampilan Gerak Nonlokomotor

Tabel 8. Analisis Data Hasil Tes Keterampilan Gerak Nonlokomotor

\begin{tabular}{llllll}
\hline \multirow{2}{*}{ No } & \multirow{2}{*}{ Jenis tes } & \multicolumn{4}{c}{ Ukuran statistik } \\
& & \multicolumn{1}{c}{} & \multicolumn{1}{c}{ SD } & \multicolumn{1}{c}{ Varian } & \multicolumn{1}{c}{ KV } \\
\hline 1. & Back up punggung & 30,35 & 5,93 & 35,24 & 19,55 \\
2. & Back up kaki & $28,01 \mathrm{~cm}$ & $7,93 \mathrm{~cm}$ & $62,90 \mathrm{~cm}$ & $28,31 \%$ \\
\hline
\end{tabular}

Keterangan:

$\overline{\boldsymbol{X}} \quad$ : rata-rata hitung

SD : standar deviasi (simpangan baku)

KV : koefisien keragama

Hasil Distribusi Frekuensi Relatif dan Kriteria Tes Back Up Punggung Siswa Putri Kelas VII MTs Negeri I Kota Malang.

Tabel 9. Distribusi Frekuensi Relatif dan Kriteria Tes Back Up Punggung Siswa Putri Kelas VII MTs Negeri I Kota Malang

\begin{tabular}{cccc}
\hline Interval & Fo & FR & Keterangan \\
\hline $42-48$ & 4 & $5 \%$ & Baik Sekali \\
$36-41$ & 11 & $12 \%$ & Baik \\
$30-35$ & 35 & $40 \%$ & Cukup \\
$24-29$ & 28 & $32 \%$ & Kurang Baik \\
$18-23$ & 10 & $11 \%$ & Tidak Baik \\
\hline
\end{tabular}

Hasil Sajian Analisis Data Bentuk Frekuensi Relatif Hasil Tes Back Up Punggung Data. 


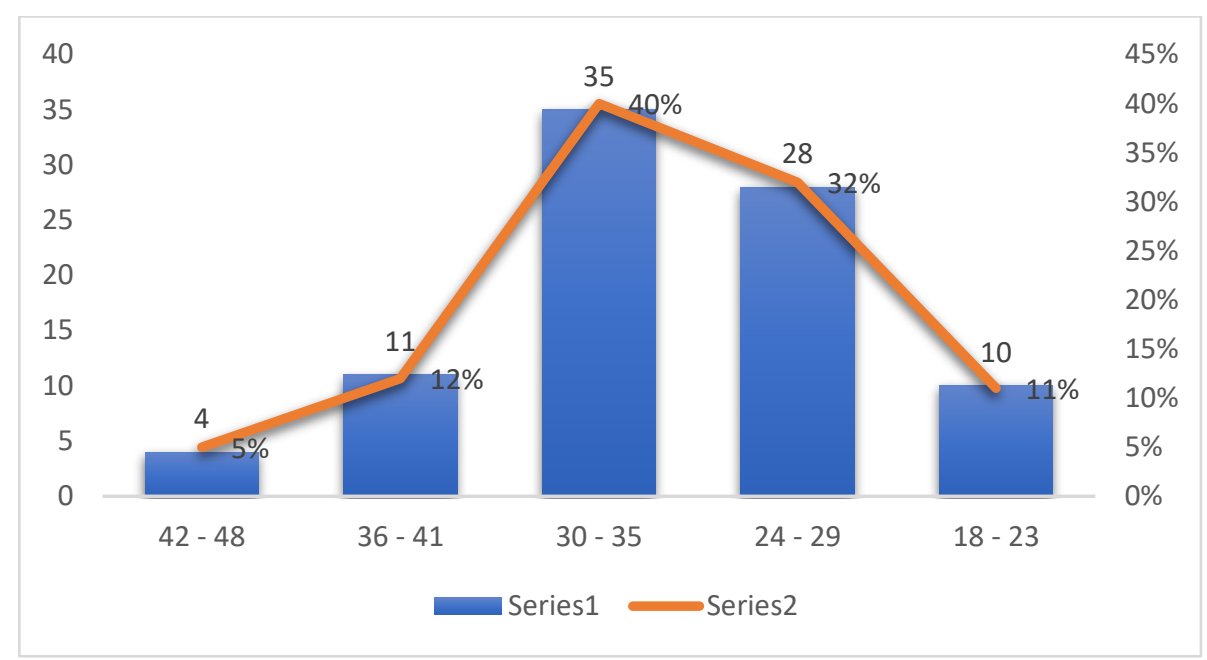

Gambar 4. Sajian Hasil Analisis Data Bentuk Frekuensi Relatif Hasil Tes Back Up Punggung Data

Hasil Distribusi Frekuensi Relatif dan Kriteria Tes Back Up Kaki Siswa Putri Kelas VII MTs Negeri I Kota Malang.

Tabel 10. Distribusi Frekuensi Relatif dan Kriteria Tes Back Up Kaki Siswa Putri Kelas VII MTs Negeri I Kota Malang

\begin{tabular}{cccc}
\hline Interval & Fo & FR & Keterangan \\
\hline $44-51$ & 1 & $1 \%$ & Baik Sekali \\
$36-43$ & 15 & $17 \%$ & Baik \\
$28-35$ & 29 & $33 \%$ & Cukup \\
$20-27$ & 32 & $36 \%$ & Kurang Baik \\
$12-19$ & 11 & $13 \%$ & Tidak Baik \\
\hline
\end{tabular}

Hasil Sajian Analisis Data Bentuk Frekuensi Relatif Hasil Tes Back Up Kaki Data

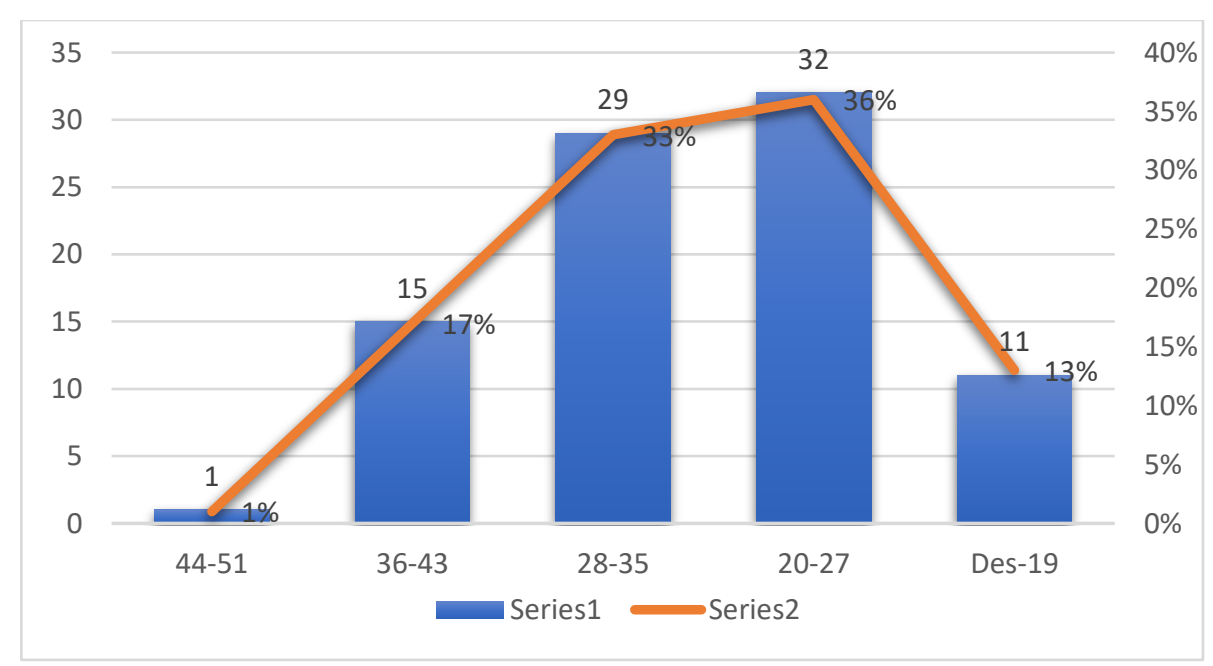

Gambar 5. Sajian Hasil Analisis Data Bentuk Frekuensi Relatif Hasil Tes Back Up Kaki Data

Hasil Analisis Data Tes Keterampilan Gerak Manipulatif 
Tabel 11. Analisis Data Hasil Tes Keterampilan Gerak Manipulatif

\begin{tabular}{clcccc}
\hline \multirow{2}{*}{ No } & \multirow{2}{*}{ Jenis tes } & \multicolumn{4}{c}{ Ukuran statistik } \\
& & $\bar{X}$ & SD & Varian & KV \\
\hline 1. & Lempar tangkap bola tenis & $8,57 \mathrm{kali}$ & $3,03 \mathrm{~cm}$ & $9,23 \mathrm{~cm}$ & $35,42 \%$ \\
2. & Chest pass & $7,86 \mathrm{kali}$ & $1,45 \mathrm{kali}$ & $2,11 \mathrm{kali}$ & $18,51 \%$ \\
\hline
\end{tabular}

Keterangan:

$\overline{\boldsymbol{X}} \quad$ : rata-rata hitung

SD : standar deviasi (simpangan baku)

KV : koefisien keragaman

Hasil Distribusi Frekuensi Relatif dan Kriteria Tes Lempar Tangkap Bola Tenis Siswa Putri Kelas VII MTs Negeri I Kota Malang

Tabel 12. Distribusi Frekuensi Relatif dan Kriteria Tes Lempar Tangkap Bola Tenis Siswa Putri Kelas VII MTs Negeri I Kota Malang

\begin{tabular}{cccc}
\hline Interval & Fo & FR & Keterangan \\
\hline $15-17$ & 1 & $1 \%$ & Baik Sekali \\
$12-14$ & 15 & $17 \%$ & Baik \\
$9-11$ & 29 & $33 \%$ & Cukup \\
$6-8$ & 25 & $28 \%$ & Kurang Baik \\
$3-5$ & 18 & $21 \%$ & Tidak Baik \\
\hline
\end{tabular}

Hasil Sajian Analisis Data Bentuk Frekuensi Relatif Hasil Tes Lempar Tangkap Bola Tenis Data.

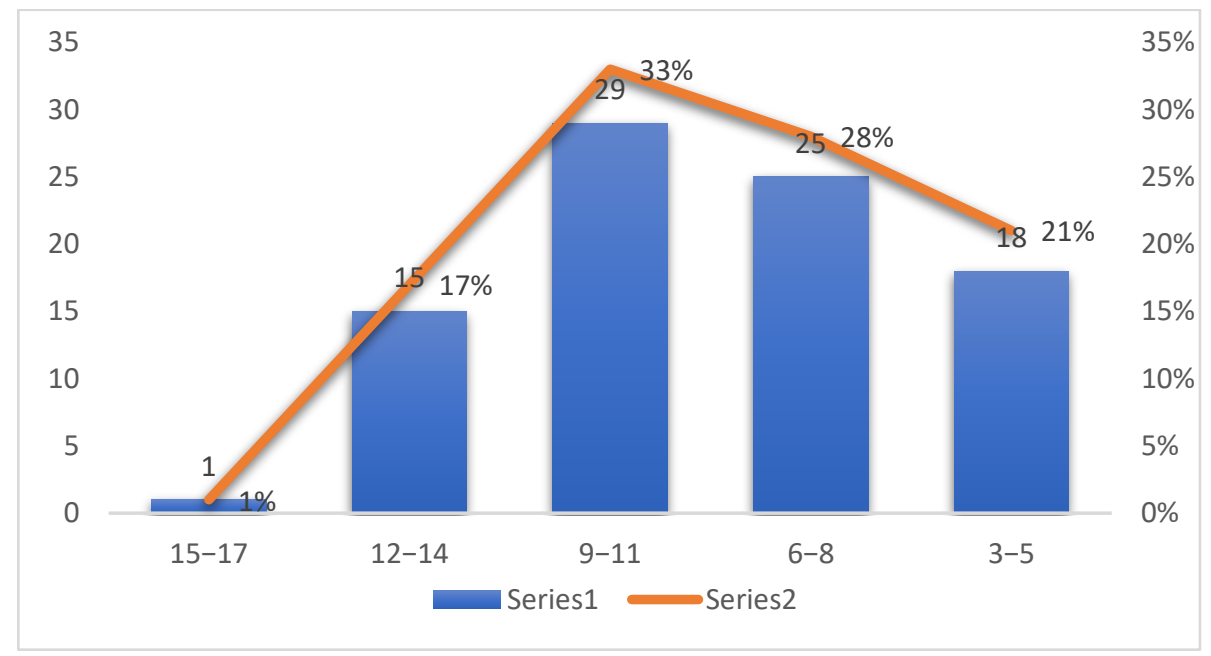

Gambar 6. Sajian Hasil Analisis Data Bentuk Frekuensi Relatif Hasil Tes Lempar Tangkap Bola Tenis Data 
Hasil Distribusi Frekuensi Relatif dan Kriteria Tes Chest Pass Siswa Putri Kelas VII MTs Negeri I Kota Malang.

\section{Tabel 13. Distribusi Frekuensi Relatif dan Kriteria Tes Chest Pass Siswa Putri Kelas VII MTs} Negeri I Kota Malang

\begin{tabular}{cccc}
\hline Interval & Fo & FR & Keterangan \\
\hline $12-13$ & 3 & $4 \%$ & Baik Sekali \\
$10-11$ & 6 & $7 \%$ & Baik \\
$8-9$ & 38 & $43 \%$ & Cukup \\
$6-7$ & 39 & $44 \%$ & Kurang Baik \\
$4-5$ & 2 & $2 \%$ & Tidak Baik \\
\hline
\end{tabular}

Hasil Sajian Analisis Data Bentuk Frekuensi Relatif Hasil Tes Chest Pass Data.

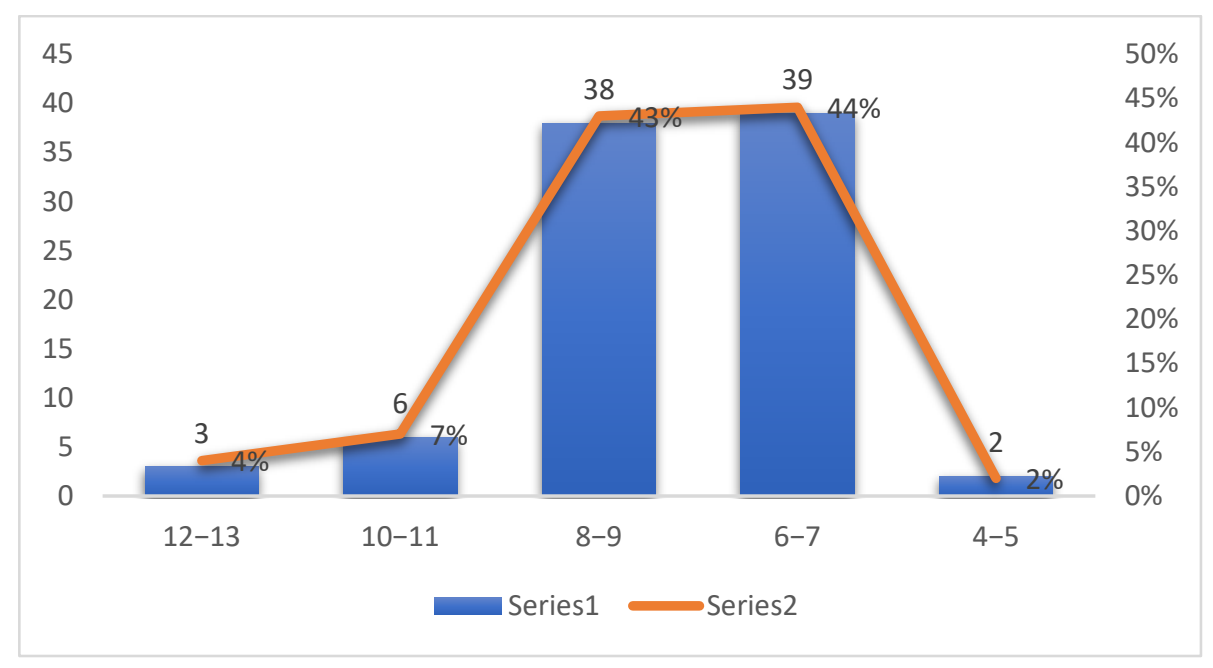

Gambar 7. Sajian Hasil Analisis Data Bentuk Frekuensi Relatif Hasil Tes Chest Pass Data

\subsection{Pembahasan}

Penelitian ini bertujuan untuk mengetahui tingkat keterampilan atau kondisi gerak dasar lokomotor, nonlokomotor dan manipulatif khususnya untuk siswa putri kelas VII MTs Negeri 1 Kota Kota Malang, berdasarkan deskripsi dan analisis data yang telah diolah menunjukan sebagai berikut.

Gerak dasar Merupakan aspek penting dalam dunia pendidikan khususnya untuk mata pelajaran pendidikan jasmani dan kesehatan. Gerak dasar merupakan dasar atau pondasi untuk mengembangkan berbagai aktivitas olahraga yang akan dilakukan atau yang diminati oleh seseorang untuk mencapai tujuan latihan yang dilakukan (Bakhtiar 2015). Sebelum mencapai tujuan dalam gerak berarti harus menguasai dasar dari gerak yang akan dilakukan tersebut guna tercapai maksud dan tujuan yang akan dilakukan seperti latihan untuk meningkatkan gerak lokomotor, nonlokomotor dan manipulatif dalam berbagai permainan atau cabang olahraga yang lain yang lebih kompleks.

Dalam pelaksanaan tes gerak lokomotor, nonlokomotor, dan manipulatif. gerak lokomotor tes yang digunakan meliputi tes lari zig - zag, loncat jauh tanpa awalan, dan lompat 
jauh menggunakan awalan. Untuk tes gerak nonlokomotor menggunakan unsur kelentukan yaitu back up punggung dan back up kaki sedangkan untuk tes gerak manipulatif menggunakan tes lempar tangkap bola tenis dan chest pass menggunakan bola tangan.

Beberapa butir tes yang diberikan terdapat butir tes yang sulit dan mempunyai tantangan bagi siswa putri, hal ini dilakukan untuk menyiapkan siswa putri supaya dapat menghadapi tantangan atau hambatan ketika pembelajaran PENJAS. Dengan adanya tantangan siswa dituntut siap menghadapi dan mengatasi hambatan atau rintangan terhadap bahan ajar yang akan diterimanya pada pembelajaran PENJAS. Adanya tantangan atau hambatan tersebut siswa menjadi bergairah dan termotivasi untuk mengatasinya dengan cara mempelajari bahan ajar yang diterimanya (Rusman, dkk. 2012). Seperti bahan yang baru dalam pembelajaran PENJAS bagi siswa baru di kelas VII merupakan materi motorik dan banyak masalah dan tantangan yang belum pernah dijumpai pada jenjang pendidikan sebelumnya. Khusus pada siswa putri kelas VII di MTs Negeri I kota Malang, tantangan atau rintangan dalam pembelajaran PENJAS harus dipelajari untuk menimbulkan motif dan memperoleh ganjaran atau terhindar dari hukuman yang tidak menyenangkan

Kondisi keterampilan gerak dasar lokomotor pada siswa putri kelas VII MTs Negeri 1 Kota Malang dibagi menjadi beberapa macam tes yang mewakili unsur lari, loncat, dan lompat. Pada hasil deskripsi dan analisis tes lari yang menggunakan instrumen tes lari zig-zag menunjukan dominan kategori baik dengan persentase sebesar 50\%, dengan jumlah siswa 44 orang siswa putri dari 88 orang, sedangkan sisanya termasuk dalam kategori cukup.dengan jumlah 44 orang (50\%). Dengan diperoleh hasil data tes gerak dasar dari unsur lari yang menunjukan dominan dalam kategori baik, dengan penggolongan dirangkap dari lima kriteria atau kelas menjadi dua kelas baik dan belum baik dengan rincian kelas baik - sangat baik tergolong (baik) sedangkan kelas cukup baik - tidak baik masuk dalam golongan (belum baik) menjadikan siswa dalam tes lari zig-zag sama sama tergolong baik dan belum baik dengan persentase $50 \%$ dan $50 \%$.

Faktor yang mempengaruhi kecepatan lari seorang anak baik yaitu, teknik, waktu reaksi dan kemauan yang keras serta bisa juga dari keturunan dan latihan (Subroto 2017). berarti seorang yang mempunyai kecepatan dalam kriteria baik bisa dipengaruhi beberapa faktor seperti yang telah di sebutkan di atas salah satunya kemauan dan latihan yang tepat dapat memengaruhi hasil kecepatan, dengan adanya kemauan yang keras serta diimbangi dengan latihan teknik yang tepat, seorang berpotensi mampu mencapai kecepatan yang baik atau maksimal.

Sedangkan untuk kelincahan dikatakan baik apabila mampu mengkoordinasikan gerakan-gerakan berganda (simultan), gerakan dilakukan secara efisien, efektif dan ekonomis (Gilang 2007). Dari hasil tes lari zig-zag menunjukan kelompok kelas baik berarti rata-rata siswa mampu melakukan gerakan secara berganda atau simultan efektif dan efisien salah satunya dipengaruhi oleh kecepatan serta kemampuan untuk merubah arah dengan cepat efektif dan efisien dari rata-rata siswa putri kelas VII di MTs Negeri 1 Kota Malang yang mengikuti tes tersebut.

Untuk lebih meningkatkan keterampilan gerak lokomotor untuk aspek lari Septi \& Wulan (2015) menyimpulkan proses kegiatan permainan lari estafet dengan modifikasi merupakan salah satu cara untuk meningkatkan kemampuan gerak lokomotor, yang dirancang berdasarkan kurikulum yang disesuaikan dengan sekolah dan kebutuhan anak. Jadi 
pembelajaran PENJAS untuk aspek lari dalam gerak lokomotor dapat ditingkatkan melalui permainan lari estafet dengan menyesuaikan kebutuhan anak atau usia dan kurikulum yang ada dalam sekolah tersebut.

Sedangkan unsur gerak lokomotor yang menggunakan tes loncat jauh tanpa awalan skor perolehan dominan dalam kategori kurang baik dengan jumlah siswa 73 orang (83\%) sisanya 15 orang dalam kondisi baik dengan besar persentase 17\% dengan jumlah siswa 15 orang. Pada tes loncat jauh tanpa awalan dominan pada kelas belum baik sebesar 73 orang siswa (83\%). Untuk tes gerak unsur lompat yang menggunakan tes lompat jauh menggunakan awalan diperoleh kelas yang paling dominan cukup baik dengan 74 siswa (84\%) dan sisanya dalam kategori baik dengan 14 orang (16\%). Tes lompat jauh menggunakan awalan siswa termasuk golongan belum baik dengan persentase sebesar (84\%) dengan 74 orang siswa dari jumlah keseluruhan 88 siswa putri.

Dari hasil tes unsur gerak lokomotor yang menggunakan tes lompat jauh menggunakan awalan dan loncat jauh tanpa awalan kedua tes tersebut dominan menggunakan aspek daya ledak otot tungkai untuk mencapai hasil yang maksimal menunjukan masing-masing tes tergolong cukup baik dan belum baik maka salah satu yang mempengaruhi lompatan siswa tersebut adalah kurangnya daya ledak pada otot tungkai. Daya ledak merupakan hasil dari kekuatan dan kecepatan, misal apabila dua orang dikatakan dapat mengangkat beban yang sama namun salah seorang tidak mampu dengan cepat mengangkat beban tersebut berarti daya ledak dikatakan kurang, juga sebaliknya (Gilang 2007).

Berarti dalam pelaksanaan lompat jauh menggunakan awalan dari hasil tes siswa putri menunjukan bahwa kecepatan berlari dan mengangkat tungkai dan tubuh siswa dikatakan belum baik karena dipengaruhi faktor lari yang kurang serta daya ledak atau mengangkat tungkai kaki serta mengangkat seluruh tubuh belum kuat. Sedangkan untuk loncat jauh tanpa awalan dipengaruhi oleh reaksi atau kurang cepat reaksi dan kurang kuatnya loncatan yang dilakukan oleh siswa putri tersebut, yang menyebabkan hasil dari loncatan tersebut dikelompokan dalam kelas yang kurang baik.

Gerak Dasar Nonlokomotor kondisi atau kemampuan gerak dibagi menjadi dua tes yang menggunakan unsur kelentukan yaitu tes back up kaki, back up punggung. Hasil tes back up punggung menunjukan atau dapat diperoleh nilai dominan pada kelas belum baik sebesar 73 orang(83\%) dengan kategori baik 15(17\%). Untuk kemampuan gerak back up kaki diperoleh hasil untuk siswa tergolong dominan dalam kelas belum baik sebesar 72 dan persentase sebesar $82 \%$ sisanya merupakan siswa putri yang mempunyai kemampuan gerak back up kaki baik.

Sedangkan dari hasil tes kemampuan siswa putri untuk mengangkat dagu dan punggung atau back up punggung dan back up kaki atau mengangkat kaki dengan posisi tengkurap lurus menunjukan belum baik, kedua tes tersebut menggunakan unsur kelentukan untuk melakukan gerakan tersebut. Ada beberapa faktor yang memengaruhi hasil kelentukan seseorang, Subroto (2017) menyatakan bahwa beberapa faktor yaitu meliputi struktur sendi, umur dan jenis kelamin, suhu tubuh dan suhu otot dan waktu dalam sehari-hari merupakan beberapa faktor yang mempengaruhi kelentukan seseorang.

Berarti dalam pelaksanaan tes yang sudah dilakukan siswa ada beberapa faktor yang mempengaruhi kelentukan siswa dalam kelas kurang baik yaitu struktur sendi yang dimiliki 
siswa, serta umur dan jenis kelamin dapat mempengaruhi hasil kelentukan yang belum baik, karena siswa yang digunakan sebagai sampel merupakan siswa putri dan masih pada jenjang sekolah menengah pertama di kelas VII serta juga memiliki tingkat kelentukan struktur sendi yang kurang baik menjadi salah satu faktor yang menyebabkan hasil kurang baik pada siswa tersebut.

Ada beberapa cara untuk melatih kelentukan salah satunya yaitu latihan peregangan teratur guna mencegah menyusutnya atau berkurangnya fleksibilitas kelentukan karena semakin bertambahnya umur. Untuk menambah jangkauan gerak sendi otot perlu direnggangkan melampaui titik batas tahanan biasanya yang dilakukan. Agar tercapai dan terjaga daya kelentukan seseorang harus melakukan latihan peregangan yang cocok dengan intensitas yang rutin.

Keterampilan Gerak Dasar Manipulatif dalam tes yang digunakan untuk unsur manipulatif yaitu tes lempar tangkap bola tenis dan chest pass. Untuk tes lempar tangkap bola tenis dominan kelas cukup baik dengan 29 orang (33\%). Jadi untuk tes lempar tangkap bola tenis tergolong kelas belum baik dengan jumlah 72 siswa (70\%). Untuk tes chest pass bola tangan dominan kurang baik dengan 39 orang siswa (44\%) jadi termasuk dalam kategori belum baik. Dengan hasil tes yang telah dilakukan menunjukan bahwa keterampilan dan kemampuan gerak belum baik.

Seperti penelitian Iivonen \& Saakslahti yang telah melakukan kajian terhadap penelitian longitudinal dan cross sectional (Iivonen, S. \& Saakslahti, 2013). Hasil yang diperoleh yaitu sebagian besar menyatakan bahwa anak laki-laki memiliki kecenderungan penguasaan kemampuan gerak dasar manipulatif yang lebih baik jika dibandingkan dengan anak perempuan. Adanya keseragaman temuan tersebut salah satunya didasarkan pada perbedaan pola aktivitas yang dilakukan oleh kedua gender tersebut baik selama di sekolah maupun di luar sekolah. Siswa laki-laki memiliki kecenderungan lebih banyak melakukan aktivitas fisik di luar ruang (outdoor) dibandingkan dengan siswa perempuan. Salah satu aktivitas dominan yang dilakukan yaitu aktivitas olahraga (Bailey dkk, 2005).

Terkait dengan gerakan manipulatif, Widodo (2015) melakukan penelitian tentang meningkatkan hasil belajar keterampilan gerak dasar manipulatif melalui pendekatan bermain pada anak Tunagrahita kelas 7 SMPLB YPAC Surakarta tahun 2014/2015 hasil penelitian ditemukan bahwa pada siklus 1 terjadi peningkatan yang signifikan dan siklus II menunjukkan peningkatan yang lebih signifikan. Kesimpulan hasil penelitian bahwa penerapan metode bermain secara signifikan dapat meningkatkan hasil belajar kemampuan gerak dasar manipulatif pada siswa kelas 7 SMP LB YPAC Surakarta.

Rahmawati (2017) menyimpulkan bahwa permainan modifikasi merupakan salah satu alternatif kegiatan atau cara dalam pembelajaran bagi anak, yang mampu memberikan kontribusi positif untuk meningkatkan kemampuan gerak manipulatif, yang meliputi kemampuan melempar, menangkap, menendang, menggelindingkan dan memantulkan bola. Kemampuan gerak dasar manipulatif tersebut pada hakikatnya merupakan salah satu capaian tugas perkembangan anak dalam aspek motorik, yang dapat membantu anak menjalani kehidupannya sehari-hari.

Hasil penelitian Hidayat (2017) menunjukkan bahwa keaktifan siswa pada gerak lokomotorik pra siklus adalah 10\% (sedang), pada gerak non lokomotorik 29\% (sedang), dan 
pada gerak manipulatif 3,3\% (sedang). Keaktifan siswa pada gerak lokomotorik siklus 1 adalah $56,6 \%$ (sedang), pada gerak non lokomotorik $76 \%$ (sedang), dan pada gerak manipulatif $60 \%$ (sedang). Keaktifan siswa pada gerak lokomotorik pra siklus adalah 80\% (tinggi), pada gerak non lokomotorik 83\% (tinggi), dan pada gerak manipulatif 86,6\% (tinggi). Melalui penerapan metode bermain Kera Panjat dalam Penelitian Tindakan kelas ini diketahui bahwa terjadi peningkatan keaktifan siswa pada gerak lokomotorik sebesar 70\%, gerak non lokomotorik $54 \%$, dan gerak manipulatif $83,3 \%$.

Tabel 14. Penyajian Kesimpulan Penggolongan Jenis Gerak Lokomotor, Nonlokomotor, dan Manipulatif (baik dan belum baik)

\begin{tabular}{lllcc}
\hline No & Jenis gerak & \multicolumn{1}{c}{ Tes } & Modus & Fo \\
\hline 1. & Lokomotor & Lari Zig-zag & $8,50 \mathrm{detik}$ & 3 \\
& & Loncat jauh tanpa awalan & $120 \mathrm{~cm}$ & 9 \\
& & Lompat jauh menggunakan awalan & $221 \mathrm{~cm}$ & 7 \\
2. & \multirow{2}{*}{ Nonlokomotor } & Back up punggung & $32 \mathrm{~cm}$ & 9 \\
& & Back up kaki & $25 \mathrm{~cm}$ & 8 \\
3. & \multirow{2}{*}{ Manipulatif } & Lempar tangkap bola tenis & $10 \mathrm{kali}$ & 15 \\
& & Chest pass & $7 \mathrm{kali}$ & 31 \\
\hline
\end{tabular}

Dalam penyajian tabel bahwa nilai yang sering muncul dari berbagai aspek lokomotor, nonlokomotor serta manipulatif yang menggunakan tes yang berbeda-beda dapat disimpulkan bahwa dalam aspek lokomotor untuk lari yang menggunakan tes lari zig-zag menunjukan bahwa skor pada siswa putri yang sering muncul adalah 8,50 detik dengan Fo= 3 dominan dalam kriteria kelas baik, untuk loncat yang menggunakan tes loncat jauh tanpa menggunakan awalan nilai yang sering muncul $120 \mathrm{~cm}$ dengan Fo= 9 dalam kriteria kelas kurang baik.

Sedangkan untuk lompat yang menggunakan tes lompat jauh menggunakan awalan skor yang paling sering muncul adalah 221 dengan $\mathrm{Fo}=7$ dalam kriteria kelas kurang baik, dapat disimpulkan bahwa dalam aspek gerak lokomotor yang menggunakan tiga jenis instrumen tes menunjukan satu banding dua karena hanya satu yang menunjukan kelas baik yaitu apek lari dan dua tes loncat dan lompat dalam kelas kurang baik menjadikan aspek lokomotor masih tergolong dalam kelas belum baik.

Nilai yang sering muncul untuk aspek nonlokomotor yang menggunakan dua instrumen tes yang masing masing menggunakan unsur kelentukan yaitu back up punggung dan back up kaki yang diukur menggunakan satuan $\mathrm{cm}$ menunjukan modus $32 \mathrm{~cm} \mathrm{Fo}=9$ untuk loncat jauh tanpa awalan dan $25 \mathrm{~cm} \mathrm{Fo=} 8$ masing-masing masuk dalam kelas cukup baik dan kurang baik, jadi dapat disimpulkan bahwa kondisi atau kemampuan nonlokomotor yang menggunakan dua instrumen tes menunjukan kondisi atau kemampuan yang belum baik.

Sedangkan untuk aspek gerak nonlokomotor yang menggunakan dua instrumen tes yaitu lempar tangkap bola tenis dan chest pass mempunyai skor yang sering muncul untuk lempar tangkap 10 kali dengan $\mathrm{Fo}=15$ dan chest pass 7 kali $\mathrm{Fo}=31$ dan masing masing tes dominan dalam kelas cukup baik dan kurang baik maka dapat disimpulkan untuk aspek gerak manipulatif tergolong masih belum baik.

Sehubungan dengan hasil berupa tes dan pengukuran menunjukan dominan pada kelas yang belum baik tersebut berarti guru penting ke depan merancang pembelajaran Pendidikan Jasmani dan Olahraga yang sistematis dan tertata dengan baik. Pembelajaran PENJAS 
bercirikan dengan aktivitas jasmani dan gerak, hal ini didukung dengan pendapat Thobroni dan Mustofa (2013) yang mengatakan bahwa dalam kegiatan belajar terdapat jenis belajar keterampilan yaitu kegiatan belajar berfokus pada pengalaman belajar melalui gerak yang dilakukan oleh siswa. Kegiatan belajar keterampilan terjadi jika siswa menerima stimulus kemudian merespon menggunakan gerak.

Berarti dalam pembelajaran pendidikan jasmani untuk mewujudkan keterampilan yang telah diajarkan dapat dikuasai, maka aktivitas pembelajaran pendidikan jasmani harus lebih difokuskan pada gerak, dan gerakan termasuk semua aktivitas kemampuan gerak dasar tubuh yang dimiliki oleh setiap individu.

Muthohir (2011) berpendapat bahwa pembelajaran pendidikan jasmani dewasa ini cenderung bersifat selektif (memilih yang terbaik) dan menekankan pada beberapa ciri yaitu individu sebagai manusia unik yang memiliki karakteristik dan kebutuhan yang bervariasi dan aktivitas gerak yang beragam. Berarti butir tes yang digunakan untuk mengukur kemampuan gerak dasar seperti unsur gerak lokomotor, nonlokomotor, dan manipulatif membantu siswa memenuhi tuntutan kebutuhan akan gerak dan menambah pengayaan berbagai aktivitas gerak dalam rangka memperoleh aktivitas yang bervariasi.

Penelitian terdahulu mengenai gerak dasar lokomotor, nonlokomotor, serta manipulatif yang telah dilakukan Rezky (2016) dengan judul "Analisis Gerak Motorik Dasar Siswa Kelas VII Smp Negeri 1 Kecamatan Kuok Kabupaten Kampar" menyimpulkan bahwa Ketiga jenis kelompok gerak dasar dijelaskan bahwa kelompok gerak Non-Lokomotor masuk dalam kategori cukup (74,5\%), lokomotor masuk dalam kategori cukup $(77,4 \%)$, dan manipulatif masuk dalam kategori baik (85,25\%). Dari hasil analisis tiga jenis kelompok gerak dasar tersebut dapat diketahui kesesuaian gerak dasar masuk dalam kategori baik (79\%).

Dari keseluruhan data siswa putri MTs Negeri I Kota Malang yang telah diolah maka telah diperoleh hasil yang belum baik dari keseluruhan tes. Prakoso dkk (2018) menyimpulkan bahwa secara umum keterampilan gerak dasar siswa putri lebih rendah dibandingkan dengan siswa putra. Permasalahan di atas tidak lepas dari peran adanya penjasorkes di sekolah sebagai salah satu mata pelajaran wajib yang memanfaatkan gerak sebagai media belajar yang akan memfasilitasi seorang siswa putri untuk lebih aktif dalam melakukan gerak.

Untuk mencapai tujuan pembelajaran dan untuk mencapai kemampuan maupun keterampilan gerak yang ingin dicapai dapat terlaksana dengan baik, maka sebaiknya para pendidik membuat strategi dan rancangan pembelajaran motorik yang efektif, matang dan tertata secara sistematis (Rahyubi, 2014). Dengan strategi yang sudah terencana dan tertata dengan baik, peluang untuk dapat mencapai tujuan dalam pembelajaran akan semakin besar, jadi pembelajaran yang efektif serta sistematis dapat dijadikan sebagai salah satu cara untuk mencapai sebuah tujuan dalam sebuah pembelajaran.

\section{Simpulan}

Hasil dari penelitian yang telah dilakukan terhadap atlet Akademi Arema Ngunut Tulungagung menunjukkan bahwa kondisi atau keterampilan gerak dasar Lokomotor yang dibagi menjadi tiga unsur gerak yaitu berlari yang menggunakan instrumen tes lari zig-zag termasuk dalam kategori baik, untuk tes loncat jauh tanpa awalan termasuk dalam kategori cukup baik, sedangkan untuk tes lompat jauh menggunakan awalan termasuk dalam kategori kurang baik, berdasarkan hasil tiga butir tes gerak lokomotor adalah dominan dalam kondisi 
belum baik. Untuk kondisi atau keterampilan gerak dasar Nonlokomotor yang menggunakan dua instrumen tes kelentukan yaitu back up punggung dominan dalam kategori kurang baik, dan untuk tes back up kaki juga sama digolongkan dalam kategori kurang baik jadi gerak nonlokomotor digolongkan dalam kondisi belum baik. Sedangkan untuk kondisi keterampilan gerak dasar Manipulatif atau kemampuan mengendalikan objek yang menggunakan dua macam butir tes yaitu tes lempar tangkap bola tenis dalam kategori cukup baik, sedangkan untuk tes chest pass yang menggunakan bola tangan digolongkan dalam kategori kurang baik. Jadi tes gerak manipulatif tergolong dalam kondisi belum baik.

\section{Daftar Rujukan}

Amien, M. 1996. Perkembangan Intelektual Siwa-siswa SMP. Jurnal Ilmu Pendidikan, 3(4), 279-292.

Bailey, R., Wellard, I., Dismore, \& H. (2005). Girls' Participation in Physical Activities and Sports: Benefits, Patterns, Influences and Ways Forward. Centre for Physical Education and Sport Research. Canterbury Christ Church University College, U.K. for the World Health Organisation (WHO).

Bakhtiar, S. (2015). Merancang Pembelajaran Gerak Dasar Anak. Padang: UNP Press

Fritz, S. (2013). Sport and Exercise Massage Comprehensive Care in Athletics, Fitness And Rehabitation. China: Elsevier.

Gallahue, D. L \& Donelly, F. C. (2003). Developmental Physical Education for All Childeren. China: Library of Congress Cataloging-In-Publication Data.

Gasong, D. (2018). Belajar dan Pembelajaran. Sleman: CV Budi Utama.

Gilang. (2007). Pendidikan Jasmani Olahraga dan Kesehatan untuk SMA. Jakarta: Ganeca Exact.

Hanief, Y. N. \& Sugito (2015). Membentuk gerak dasar pada siswa sekolah dasar melalui permainan tradisional. JOURNAL OF SPORTIF, 1(1), 60-73.

Hidayat, A. (2017). Peningkatan aktivitas gerak lokomotor, nonlokomotor dan manipulatif menggunakan model permainan pada siswa sekolah dasar. Jurnal Pendidikan Jasmani Dan Olahraga, 2(2), 21-29.

Hurlock, E. B. (2010). Psikologi Perkembangan suatu Pendekatan Sepanjang Rentang Kehidupan. Jakarta: Erlangga

Iivonen, S., \& Sääkslahti, A. K. (2014). Preschool children's fundamental motor skills: a review of significant determinants. Early Child Development and Care, 184(7), 1107-1126.

Lantai, G. P. (2014). Jurnal Olahraga dan Pendidikan. Jakarta: Asisten Deputi Olahraga Pendidikan Deputi Bidang Pembudayaan Olahraga.

Mu'arifin. (2009). Dasar-Dasar Pendidikan Jasmani dan Olahraga. Malang: UM Press.

Prakoso, B. B., Saifuddin, H., \& Burstiando, R. (2013). Keterampilan Gerak Dasar Siswa Kelas atas MI Miftahul Ulum 3 Pereng Kulon Gresik. In Seminar Nasional "Inovasi Pembelajaran Penjasorkes Pada Kurikulum.

Mirawati, M., \& Rahmawati, E. (2017). Permainan Modifikasi untuk Stimulasi Keterampilan Gerak Dasar Manipulatif Anak Usia 2-4 Tahun. Early Childhood: Jurnal Pendidikan, 1(2), 38-50.

Rahyubi, H. (2012). Teori-Teori Belajar dan Aplikasi Pembelajaran Motorik. Magelang: Nusa Media.

Rahyubi, H. (2014). Teori-Teori Belajar dan Aplikasi Pembelajaran Motorik. Bandung: Nusa Media.

Rusman, Kurniawan, D \& Riayana, C. (2012). Pembelajaran berbasis Teknologi Informasi dan Komunikasi. Mengembangkan Profesionalisme Guru. Depok: Raja Grafindo Persada

Rusman. (2017). Belajar dan Pemebelajaran Berorientasi Standar Proses Pendidikan. Jakarta: Kencana.

Soemarjadi, M. R., \& Zahri, W. (1991). Pendidikan Keterampilan. Depdikbud, Jakarta.

Suardi. M. (2018). Belajar dan Pemebalajaran. Yogyakarta: CV Budi Utama

Subroto. 2017. Modul Pelatihan Pelatih Fisik Olahraga Level 1. Jakarta: Koni Pusat.

Subroto. 2017. Modul Penataran Pelatih Olahraga Tingkat Pemula. Jakarta: Koni Pusat

Sugiyono. (2009). Metode Penelitian Administrasi. Bandung: Alfabeta 
Thobroni, M. \& Mustofa, A. (2013). Belajar dan Pemebelajaran Pengembangan Wacana dan Praktik Pemebelajaran dalam Pembangunan Nasional. Yogyakarta: AR Ruzz Media.

Upton. (2012). Seri Belajar Cepat Psikologi: Psikologi Perkembangan Edisi Ke-1. Diterjemahkan oleh: Noermalasari Fajar Widuri. Jakarta: Erlangga.

Wulan, D. S. A. (2015). Melalui Permainan Lari Estafet Modifikasi (Penelitian Tindakan di TK B Jihan Ulfani Kecamatan Medan Marelan Tahun 2014/2015). Jurnal Pendidikan Usia Dini.

Wiarto, G. (2015). Inovasi Pembelajaran dalam Pendidikan Jasmani. Yogyakarta: Laksitas.

Widodo, Z. D. (2015). Meningkatkan Hasil Belajar Keterampilan Gerak Dasar Manipulatif melalui Pendekatan Bermain pada Anak Tunagrahita Kelas 7 SMPLB YPAC Surakarta.

Wijaya, H., \& Helaluddin. (2018). Hakikat Pendidikan Karakter.

Yudrik. \& Jahja. (2011). Psikologi Perkembangan. Jakarta: Kencana. 